\title{
ECONOMY
}

\section{SELECTED ASPECTS OF MODELING THE PROCESS OF EVALUATING BUSINESS STRATEGIES FOR SUSTAINABLE ECONOMIC DEVELOPMENT OF IRON ORE ENTERPRISES}

\author{
Yevhen Afanasiev, \\ Kryvyi Rih National University, Department of Management and Administration, Kryvyi Rih, Ukraine \\ Serhiy Kapitula, \\ Kryvyi Rih National University, Department of Finance of Entrepreneurs and Innovative \\ Development, Kryvyi Rih, Ukraine \\ Mariia Afanasieva, \\ Kryvyi Rih National University, Department of Higher Mathematics, Kryvyi Rih, Ukraine \\ Ihor Afanasiev, \\ Kryvyi Rih National University, Department of Management and Administration, Kryvyi Rih, Ukraine \\ Pavlo Demchenko, \\ Kryvyi Rih National University, Department of Management and Administration, Kryvyi Rih, Ukraine
} DOI: https://doi.org/10.31435/rsglobal_ijite/31052020/7065

\section{ARTICLE INFO}

Received 10 March 2020

Accepted 02 May 2020

Published 31 May 2020

\section{KEYWORDS}

modeling,

business strategy,

stable economic

development,

iron ore enterprises.

\begin{abstract}
The theoretical principles of modeling the process of evaluation of business strategies for ensuring sustainable economic development of iron ore enterprises are considered in the article, taking into account the current state of the domestic economy. The basic model of the situation of making a rational decision concerning the problem of optimization of business strategies in the conditions of uncertainty and conflict of the market environment is defined, which is a generalized matrix of the problem of mathematical programming, the solution of which is the optimal parameters of a mixed strategy for managing the sustainable development of iron ore enterprise. The procedure of multicriteria game-theoretic evaluation of alternatives in the application of mathematical theory of conflict situations in the work is recommended to be carried out according to a certain algorithm, which reflects the sequence of stages of modeling the effective evaluations of individual business strategies when using the functionals of evaluation with negative, but continuous. In the work it is proved that not only research of their optimality but also issues related to forecasting a guaranteed positive positive result is of particular importance when forming situations of financial and economic substantiation and making management decisions regarding individual business strategies of the enterprise. As a result of using the proposed methodological approaches, this study achieves a scientifically sound isolation of certain key business processes of the enterprise's production and economic system in order to carry out more in-depth analysis of problematic business operations and to make adequate strategic decisions regarding the prospects of sustainable economic development of the iron ore enterprises.
\end{abstract}

Citation: Yevhen Afanasiev, Serhiy Kapitula, Ihor Afanasiev, Mariia Afanasieva, Pavlo Demchenko. (2020) Selected Aspects of Modeling the Process of Evaluating Business Strategies for Sustainable Economic Development of Iron ore Enterprises. International Journal of Innovative Technologies in Economy. 2(29). doi: 10.31435/rsglobal_ijite/31052020/7065

Copyright: (C) 2020 Yevhen Afanasiev, Serhiy Kapitula, Ihor Afanasiev, Mariia Afanasieva, Pavlo Demchenko. This is an open-access article distributed under the terms of the Creative Commons Attribution License (CC BY). The use, distribution or reproduction in other forums is permitted, provided the original author(s) or licensor are credited and that the original publication in this journal is cited, in accordance with accepted academic practice. No use, distribution or reproduction is permitted which does not comply with these terms. 


\section{Introduction and problem statement.}

In today's conditions of production and economic activity of enterprises of iron ore industry the key task of top management, as the central link of business process management, is the formation of competitive corporate (general) strategy of sustainable economic development on the basis of providing business strategies of individual business units taking into account the interests of the national economy. In the complex, a set of business strategies of an enterprise should have such an important property as ensuring timely anticipation of the changes taking place in its market space. If necessary, the necessary adjustments are made to certain aspects of management in the context of the general strategy of sustainable development of the enterprise formed and, as a result, the desired production, financial, economic indicators are achieved and its competitive advantages are ensured.

This provides an opportunity to highlight the relevance of the strategy of sustainable economic development of the iron ore industry as a basis for the rational management of its business strategies in the process of production and economic activity in the context of environmental variability. However, the effectiveness of the iron ore enterprise depends largely on the rational justification of management decisions based on the analysis of effective financial and economic indicators aimed at increasing the level of economic potential by maximizing the involvement of all available resources of its business units in the production process.

Analysis of recent research and publications. Based on the analysis of literature sources, it has been established that the problems of sustainable economic development of industrial enterprises have received much attention in recent years. In particular, a number of scientists are considering the sustainable development of iron ore enterprises from different sides, often using a serious mathematical apparatus for conducting relevant research. So, works 1, 2 discuss the optimization of development strategies of iron ore enterprises, $6-$ the assessment of the influence of competitive activity of the market environment on the efficiency of use of labor potential, in 11 - looks at sustainable economic development based on an economic security strategy and more.

Forming the purpose of the article. The purpose of the article is to formulate the basic methodological bases for modeling the process of evaluating business strategies for sustainable economic development of iron ore enterprises.

Research results. The constant transformations in the market space, the functioning of the iron ore enterprise at national borders of the economy determine the important role of the provision of its own financial resources. In this case, the company has the certainty of having good financial sustainability, high financial independence and, as a consequence, its high investment attractiveness. At the same time, a sufficiently large share of own financial resources contributes to the high level of creditworthiness, and therefore the possibility of attracting a sufficient amount of borrowed funds in order to further develop production and economic processes and increase their efficiency.

Summarizing, it can be stated that the production and economic activity of the enterprise under market conditions should be based on the principles of self-sufficiency and self-financing. In most enterprises, these principles remain unfulfilled. The main reasons are the mismatch of the production capacity of the enterprise to the conditions of a market economy. The reasons for the discrepancy are very different, among them discrepancies: technologies and equipment of modern level; quality of products to the needs of consumers; between prices and costs, etc.

Therefore, bringing the economic mechanism of the enterprise to market conditions is the most important task of management. At the same time it is necessary to clearly define the structure of the production and economic mechanism, capable of constantly adapting to periodic changes of the conditions of functioning of the enterprise in the market space. However, it should be borne in mind that the in-house form of management of the iron ore enterprise has three main levels:

- management technology for the production of iron ore products;

- technology of balancing production and sales of different types of iron ore products;

- technology of management of internal and external communications of the enterprise.

So, in order to ensure the necessary efficiency of the process of adaptation of the iron ore enterprise to periodic changes in the conditions of management in the market space, the financial and economic justification of the corrective management decisions regarding the functioning of its individual business units should be carried out in a complex relation to the above mentioned basic levels of intraproduction management of the enterprise - investment programs. At the same time, the main purpose of the process of adaptation of business units of the enterprise in the conditions of volatility of market space 
is directed to the solution of such important tasks of managing its production and economic activity: reducing the cost and ensuring high quality of iron ore products, increasing its profitability.

Establishment of the existing interconnections and interdependence between the financial and economic aspects of the functioning of the resource-production system of the iron ore enterprise allows to make appropriate calculations for comparison of different alternative variants of its adaptation in the conditions of market space volatility in terms of production volumes, costs and sales prices; to compare the effectiveness of alternative options and to select the most appropriate for the complex development and rational development of mineral resources and the rational use of production and economic potential of the enterprise.

The formulation of this scientific research and the preliminary generalization of its individual key aspects give grounds to argue for the need for further development and use in the process of adaptation of business strategies of iron ore enterprise in the implementation of production and economic activity in the conditions of variability of the external environment of the theory and methodology of rational financial and economic rationale functioning of its resource-production system.

It should be noted that the modeling of management decisions should be carried out on the basis of data on the effective financial and economic indicators in both retrospective and in the forecasted periods. So, in general, we are dealing with situations of justification of financial and economic decisions in the conditions of uncertainty and conflict. Thus, it is advisable to use an information situation classifier in the simulation process (IS) [5, p. 241-242]:

IS1 - the distribution of a priori probabilities on the states of the economic environment is given;

IS2 - the distribution of a priori probabilities on the states of the economic environment, where its accuracy is determined to unknown parameters;

IS3 - there is some set of constraints on a given distribution of a priori probabilities in economic conditions;

IS4 - conditions are fulfilled: the distribution of a priori probabilities on the states of the economic environment is unknown and there is no active counteraction to the achievement of the result;

IS5 - there is an active counteraction to the economic environment to achieve results;

IS6 - there is some information about the distribution of a priori probabilities in the states of the economic environment and its partial antagonism;

IS7 - states of the economic environment form a fuzzy set.

Analysis of the features of iron ore enterprises functioning shows $[1,2,6,12]$ that the information situations of IS4 and IS5 are the most practical in modeling the management decisions in the process of adaptation of business strategies of the iron ore enterprise in the implementation of production and economic activity in the conditions of market space volatility.

Criteria for these information situations should be used in evaluating the implementation of various innovations, in particular: the development and improvement of technological processes, equipment, new samples of consumer goods in the face of completely unknown demand, the laying of new transport routes, etc. Therefore, based on these information situations, the justification and decision making of financial and economic decisions in the conditions of uncertainty and conflict will be guided by the choice of their characteristic criteria. In particular, for IS4, we use the BernoulliLaplace criterion based on the principle of insufficient basis and the Khomenyuk criterion in which the probabilities of economic conditions are determined on the basis of the concept of «potential probability distribution».

The estimated value of alternatives according to the Bernoulli-Laplace criterion for the functional of the evaluation with the positive ingredient $\left(F=F^{+}\right)$is calculated by the formula:

$$
B^{+}\left(x_{i_{o}}, p\right)=\max _{x_{i} \in X}\left\{\frac{1}{n} \sum_{j=1}^{n} f_{i j}^{+}\right\},
$$

where $B^{+}\left(x_{i,}, p\right)$ - optimal positive value of quantification according to the Bernoulli-Laplace criterion; $x_{i_{o}}$ - designation of the variable «optimal alternative»; $p$ - probability; $x_{i}-i$-th alternative variant; $X=\left\{x_{1}, x_{2}, \ldots, x_{m}\right\}$ - many alternatives variants; $n$ - the set of states of an economic person; $f_{i j}^{+}$ - quantitative positive evaluations of the evaluation functional. 
Other variants of the other variants for the Khomenyuk domain for functional evaluation with a positive ingredient $\left(F=F^{+}\right)$is revealed as a mathematical notification, where the vector anonymous probabilities $\hat{p}$ are revealed by the formula:

$$
\hat{p}_{j}=\frac{\sum_{i=1}^{m}\left(\max _{x_{i} \in X} f_{i j}^{+}-f_{i j}^{+}\right)}{\sum_{j=1}^{n} \sum_{i=1}^{m}\left(\max _{x_{i} \in X} f_{i j}^{+}-f_{i j}^{+}\right)},
$$

and for $F=F^{-}$

$$
\hat{p}_{j}=\frac{\sum_{i=1}^{m}\left(f_{i j}^{-}-\min _{x_{i} \in X} f_{i j}^{-}\right)}{\sum_{j=1}^{n} \sum_{i=1}^{m}\left(f_{i j}^{-}-\min _{x_{i} \in X} f_{i j}^{-}\right)} .
$$

Note: in the case of evaluating functionals with a negative ingredient $\left(F=F^{-}\right)$for the specified criteria, the estimated values of the alternatives are investigated to a minimum.

For IS5, we use the Waldo and Sevid criteria.

Wald's criterion: The main objective of the management entity in this situation is to provide itself with guaranteed (maximum) levels of values of the evaluation functionality. For $F=F^{+}$, in accordance with the principle of "maximum" is considered the optimal solution $x_{i_{o}} \in X$, in which the corresponding figure is maximum:

$$
\tilde{f}_{i_{o}}^{+}=\max _{x_{i} \in X} \min _{\theta_{j} \in \Theta}\left\{f_{i j}^{+}\right\},
$$

so, the optimal solution is the one that leads to the best of the worst values of the valued functional.

Savage's criterion: The Sevid criterion is used for $F=F^{-}$. This criterion recommends that in an uncertain environment, choose the strategy in which the size of the risk $\left(r_{i j}\right)$ takes the least value in the most unfavorable situation (satisfies the principle of «minimum»). The optimal solution is a solution that satisfies the condition:

$$
\tilde{f}_{i_{o}}^{-}=\min _{x_{i} \in X} \max _{\theta_{j} \in \Theta}\left\{r_{i j}\right\} .
$$

However, the proposed approaches of criterion estimation apply only to solving local problems of optimization of individual indicators (parameters) of production and economic activity of business structures through which they try to increase the level of stability of economic development of an enterprise in the conditions of market transformations. However, involving in the solution of the problem of this scientific research methodological approaches to the theory of justification and making multi-purpose management decisions can reduce the problem of optimizing business strategies to the multicriteria problem of mathematical programming. In the process of economic and mathematical modeling of evaluations of the effectiveness of business strategies of the iron ore enterprise it is necessary to use a complex approach and appropriate methodology and optimization tools, which are based on a systematic approach in forming a set of key financial and economic indicators for evaluating alternative solutions.

The basic model of the situation of making a rational decision regarding the problem of optimization of business strategies in the conditions of uncertainty and conflict of the market environment is a generalized matrix of dimension $m \times n$ (the matrix of the problem of mathematical programming the solution of which are the optimal parameters of a mixed strategy for managing the sustainable development of iron ore).

So, the procedure of multicriteria game-theoretic evaluation of alternatives in the application of mathematical theory of conflict situations can be recommended to be carried out according to the algorithm shown in picture 1, where dashed lines reflect the sequence of steps of modeling the performance appraisals of individual business strategies when using the appraisal functionalities with a negative, and continuous with a positive ingredient [5, p. 243-244].

In forming the situations of financial and economic justification and making management decisions regarding individual business strategies of the enterprise, not only the study of their 
optimality but also the issues related to the forecasting of the guaranteed stable positive result is of particular importance. In order to solve these problems, it is advisable to present local business strategies of the enterprise with multi-purpose evaluation functionality [1, p. 141]:

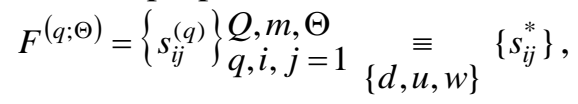

where $s_{i j}^{(q)}, s_{i j}^{*}$ - quantitative evaluations of local business strategies of the iron ore enterprise, where $i=\overline{1, m}, j=\overline{1, n} ; q=\overline{1, Q}$ - source matrix tables (separate functionals for evaluating key financial and economic indicators); $\Theta$ - set of economic conditions in mathematical formulation of the problem of optimization of local business strategies of iron ore enterprise, where $j=\overline{1, n} ;\{d, u, w\}$ - factors of normalization procedure $(d)$ and taking into account priorities $(u)$, convolution criteria $(w)$.

The formalized procedure (6) involves the integrated transformation of individual functionals (tables-matrices) formed from key financial and economic indicators of the business units of an iron ore enterprise into a matrix of a mathematical programming problem to determine the optimal parameters of its mixed sustainable development strategy.

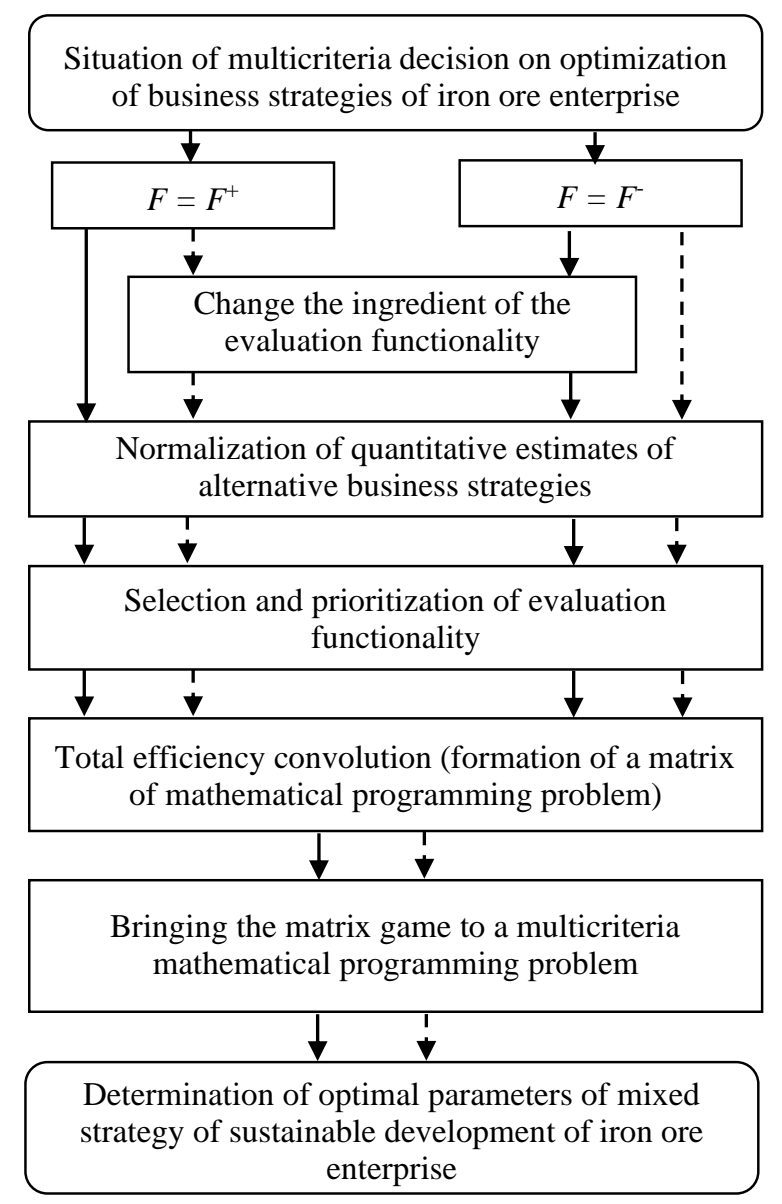

Fig. 1. The sequence of stages of the procedure of multicriteria game-theoretic evaluation of alternative business strategies of iron ore enterprise

Generalized problem of mathematical programming in optimization of a set of local business strategies of an iron ore enterprise can be written in this form:

$$
\begin{gathered}
Z=\sum_{i=1}^{m} x_{i}=\sum_{i=1}^{m} \frac{p_{i}}{v}=\frac{1}{v} \rightarrow \min ; \\
\sum_{i=1}^{m} s_{i j}^{*} x_{i} \geq 1 \text { at } x_{i} \geq 0, i=\overline{1, m} ; j=\overline{1, n},
\end{gathered}
$$


where $v$ - the price of a matrix game for a mixed strategy for the sustainable development of an iron ore enterprise; $p_{1}, p_{2}, \ldots, p_{i}, \ldots, p_{m}$ - the probability of using separate business strategies in a mixed strategy for the sustainable development of an iron ore enterprise. These probabilities serve as weighting factors in the process of forecasting (estimating) and forming an optimal strategy for ensuring sustainable economic development of the iron ore enterprise, where its formalized formulation is as follows:

$$
S^{*}=\left(p_{1}, p_{2}, \ldots, p_{i}, \ldots, p_{m}\right), \text { where } \sum_{i=1}^{m} p_{i}=1 .
$$

Consider, by way of practical example, the implementation of the proposed methodological approach to assessing the strategy of sustainable economic development of mining enterprises of the iron ore industry based on the function of the following key indicators: enterprise assets, profit and level of monopolization of the market of iron ore products, taking into account the evenness of distribution.

For this purpose we will select three private joint-stock companies (PJSC), three leading enterprises of the national mining and metallurgical complex: «Ingulets Mining and Processing Works» (PJSC «InGZK»), «Northern Mining and Processing Works» (PJSC «PivnGZK»), «Central Mining and Processing Works» (PJSC «CGZK»). The situation at these mining enterprises is typical of such enterprises, and therefore the study is representative.

Tables 1-3 show the dynamics of assets, profits and the level of monopolization of the market for iron ore mining and quarrying for the period 2012-2017.

Table 1. Assets dynamics of mining and processing enterprises for the period 2012-2017, mln. UAH

\begin{tabular}{|c|c|c|c|}
\hline Periods & PJSC «InGZK» & PJSC «PivnGZK» & PJSC «CGZK» \\
\hline 2012 & 23503,8 & 22089,1 & 7405,9 \\
\hline 2013 & 24694,3 & 21821,4 & 7822,8 \\
\hline 2014 & 31002,2 & 32400,2 & 6573,3 \\
\hline 2015 & 36672,8 & 29624,8 & 7426,4 \\
\hline 2016 & 40485,9 & 38176,5 & 12610,8 \\
\hline 2017 & 49006,3 & 47503,9 & 14212,4 \\
\hline
\end{tabular}

Table 2. Profit dynamics of mining and processing enterprises for the period 2012-2017, mln. UAH

\begin{tabular}{|c|c|c|c|}
\hline Periods & PJSC «InGZK» & PJSC «PivnGZK» & PJSC «CGZK» \\
\hline 2012 & 4766,4 & 3534,5 & 761,2 \\
\hline 2013 & 4712,6 & 4441,6 & 1572 \\
\hline 2014 & 976,2 & 1545,7 & 770,8 \\
\hline 2015 & $-3498,9$ & $-1212,5$ & 688 \\
\hline 2016 & $-69,3$ & 3613,1 & 2218,2 \\
\hline 2017 & 5711,3 & 7791,8 & 2707,9 \\
\hline
\end{tabular}

Table 3. Dynamics of the level of monopolization of the market of iron ore products, taking into account the uniform distribution of market shares (according to the Herfindahl-Hirschman index) of mining and processing enterprises for the period 2012-2017.

\begin{tabular}{|c|c|c|c|}
\hline Periods & PJSC «InGZK» & PJSC «PivnGZK» & PJSC «CGZK» \\
\hline 2012 & 0,078 & 0,069 & 0,008 \\
\hline 2013 & 0,074 & 0,057 & 0,007 \\
\hline 2014 & 0,066 & 0,072 & 0,003 \\
\hline 2015 & 0,080 & 0,052 & 0,003 \\
\hline 2016 & 0,067 & 0,060 & 0,007 \\
\hline 2017 & 0,073 & 0,069 & 0,006 \\
\hline
\end{tabular}

Using the factors of the normalization procedure (Table 4) and the convolution of total efficiency to the estimation functionals presented in Tables 1-3, we obtain the matrix of the mathematical programming problem (Table 5). 
Table 4. Methods of normalization

\begin{tabular}{|c|c|}
\hline Normalization & Mathematical notation \\
\hline Relative & $\left(f_{i}^{q} / \max _{i} f_{i}^{q}\right),\left(f_{i}^{q} / \min _{i} f_{i}^{q}\right)$ \\
\hline Natural & $\left(f_{i}^{q}-\min _{i} f_{i}^{q}\right) /\left(\max _{i} f_{i}^{q}-\min _{i} f_{i}^{q}\right)$ \\
\hline
\end{tabular}

Table 5. Mathematical programming problem matrix

\begin{tabular}{|c|c|c|c|}
\hline Periods & PJSC «InGZK» & PJSC «PivnGZK» & PJSC «CGZK» \\
\hline 2012 & 1 & 0,83992 & 0,09568 \\
\hline 2013 & 1 & 0,85114 & 0,12512 \\
\hline 2014 & 0,77114 & 1 & 0,12379 \\
\hline 2015 & $-0,18094$ & 0,27347 & 0,37392 \\
\hline 2016 & 0,66347 & 0,93776 & 0,27394 \\
\hline 2017 & 0,88729 & 0,96664 & 0,12028 \\
\hline
\end{tabular}

The next step is to reduce the matrix game to a multicriteria mathematical programming problem (we obtain the linear programming problem of the form (7) - (8)):

$$
\left\{\begin{array}{r}
x_{1}+0,84 x_{2}+0,096 x_{3} \geq 1 \\
x_{1}+0,851 x_{2}+0,125 x_{3} \geq 1 \\
0,771 x_{1}+x_{2}+0,124 x_{3} \geq 1 \\
-0,181 x_{1}+0,273 x_{2}+0,374 x_{3} \geq 1 \\
0,664 x_{1}+0,938 x_{2}+0,274 x_{3} \geq 1 \\
0,887 x_{1}+0,967 x_{2}+0,12 x_{3} \geq 1 \\
x_{i} \geq 0, i=\overline{1,3} \\
Z=x_{1}+x_{2}+. x_{3} \rightarrow \min .
\end{array}\right.
$$

According to the results of the solution of the optimization problem (10) - (12), using the relationship between the variables of function (7) we obtain the probabilities - the weighting coefficients of the evaluation of the strategy of ensuring the sustainable economic development of enterprises (PJSC «InGZK», PJSC «PivnGZK», PJSC «CGZK»): $S^{*}=(0 ; 0,33 ; 0,67)$.

The results of the calculations show that the highest level of sustainable economic development has PJSC «CSGK» and a sufficient level has PJSC «NorthGZK». The zero value of the coefficient of evaluation of the strategy for ensuring sustainable economic development for PJSC «InGZK» indicates periodic negative tendencies in the development of this enterprise. This is confirmed by the dynamics of profit of the mining and processing enterprises analyzed in this work for 2012 - 2017 (Figs. 2 - 4).

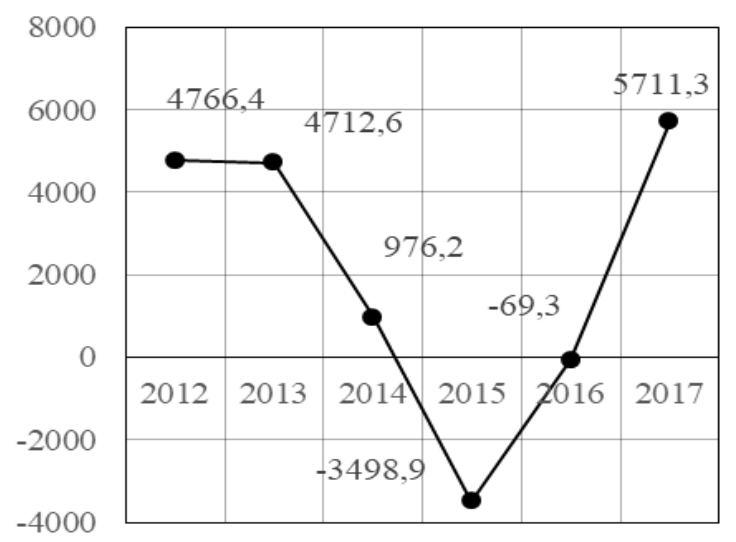

Fig. 2. Profit dynamics of PJSC «InGZK» for the period 2012-2017, mln. UAH. 


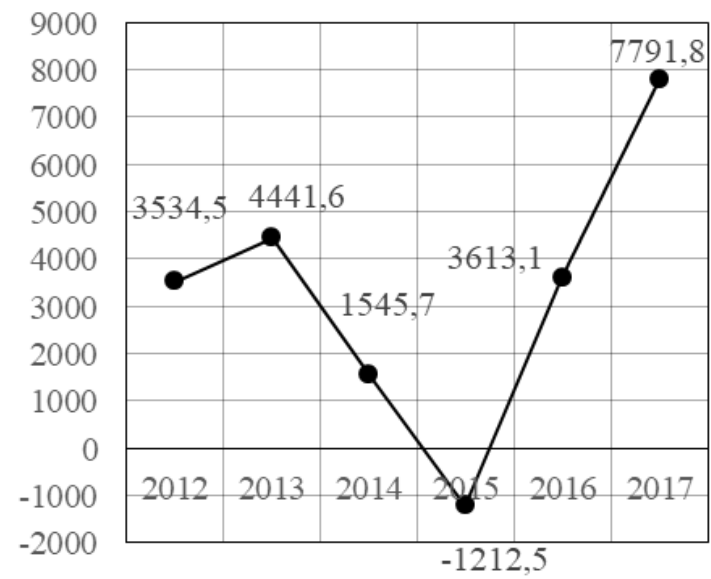

Fig. 3. Profit dynamics of PJSC «NorthGZK» for the period 2012-2017, mln. UAH.

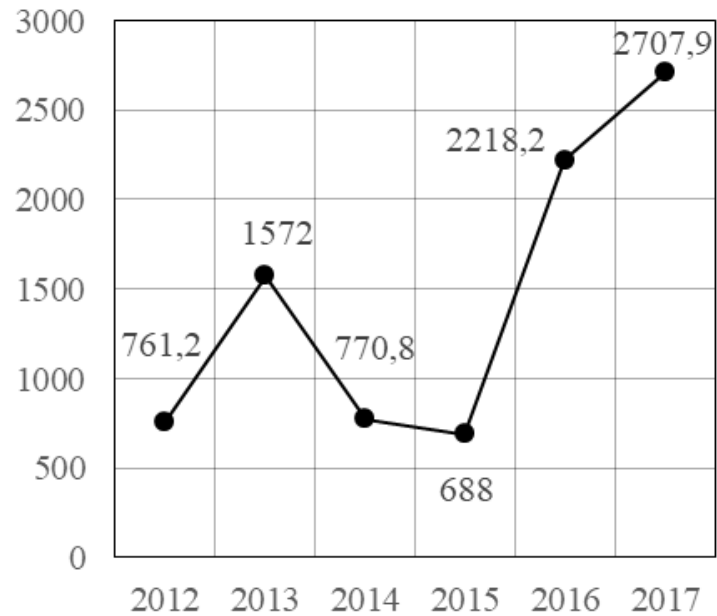

Fig. 4. Profit dynamics of PJSC «CSGK» for the period 2012-2017, mln. UAH.

Conclusions. Therefore, in our opinion, in the theoretical and methodological basis of the study of modeling processes of evaluation and forecasting of business strategies for ensuring sustainable economic development of iron ore enterprises should be laid: complex system-situational approaches for monitoring and diagnostics of financial and economic indicators of the results of production and economic activity; methods of the theory of substantiation of multipurpose multicriteria solutions and mathematical programming. As a result of using the proposed methodological approaches, this study achieves a scientifically sound isolation of certain key business processes of the enterprise's production and economic system in order to carry out more in-depth analysis of problematic business operations and to make adequate strategic decisions regarding the prospects of sustainable economic development of the iron ore enterprises.

\section{REFERENCES}

1. Afanas`yeva M.G., Popov V.Yu. (2011) Teorety`ko-igrovy`j pidxid opty`mizaciyi zmishanoyi finansovoekonomichnoyi strategiyi girny`chorudnogo pidpry'yemstva [Theoretical and game approach to optimization of mixed financial and economic strategy of a mining enterprise]. Visny`k Dnipropetrovs kogo universy tetu. Seriya «Ekonomika». [Bulletin of Dnipropetrovsk University. Economics series]. No 5 (4). Pp. 138-143. (in Ukrainian).

2. Afanas'yev Ye.V., Afanas'yeva M.H., Vorobyov R.B. (2019) Modelyuvannya zmishanykh stratehiy innovatsiynoho rozvytku zalizorudnykh pidpryyemstv $v$ umovakh rynkovykh peretvoren' [Modeling of mixed strategies of innovative development of iron ore enterprises in the conditions of market transformations.]. Science Review. Poland. No 4 (21). Pp. 40-47 (in Ukrainian).

3. Bohatyr'ov I.I. (2014) Imperatyvy formuvannya $i$ realizatsiyi finansovoyi stratehiyi korporatsiyi [Imperatives of formation and realization of financial strategy of corporation] // Stratehichnyy menedzhment na pidpryyemstvi. Stratehiya ekonomichnoho rozvytku Ukrayiny. [Strategic management at the enterprise. Strategy of economic development of Ukraine]. No34. Pp 124-129. (in Ukrainian). 
4. Vasyl'tsiv T.H. (2011) Okreslennya stratehiyi zmitsnennya ekonomichnoyi bezpeky pidpryyemnytstva $z$ pohlyadu systemnoho pidkhodu na yiyi mistse u systemi bezpeky derzhavy [Outlining the strategy of strengthening the economic security of entrepreneurship in terms of a systematic approach to its place in the security system of the state]. Stratehiya rozvytku Ukrayiny (ekonomika, sotsiolohiya, pravo). [Development Strategy of Ukraine (economics, sociology, law)]. No 4, vol. 1. Pp. 37-43. (in Ukrainian).

5. Vitlins'kyy V.V. (2004) Ryzykolohiya $v$ ekonomitsi ta pidpryyemnytstvi: Monohrafiya [Risicology in economics and entrepreneurship: Monograph]. Kiyv. 2004. 480 p. (in Ukrainian).

6. Vorobyov R.B., Het'man A.O., Yakovets' O.O. (2019) Monitorynh konkurentnoyi aktyvnosti rynkovoho seredovyshcha zalizorudnoho pidpryyemstva ta yoho vplyv na efektyvnist' vykorystannya trudovoho potentsialu [Monitoring the competitive activity of the market environment of the iron ore enterprise and its impact on the efficiency of labor potential]. Skhidna Yevropa: ekonomika, biznes ta upravlinnya [Eastern Europe: Economics, Business and Management] No 4(21). (in Ukrainian).

7. Ivanov Yu.B., Ivanova O.Yu. (2012) Stratehiya formuvannya konkurentnykh perevah pidpryyemstva $v$ umovakh intensyvnoyi konkurentnoyi borot'by problemy ekonomiky [Strategy of formation of competitive advantages of the enterprise in the conditions of intensive competition of a problem of economy]. Problemy ekonomiky. [Problems of the economy.]- No 4. Pp. 121-128. (in Ukrainian).

8. Kantayeva O.V., Batishchyeva N.M. (2011) Napryamy ta pryntsypovi polozhennya rozvytku suchasnoho stratehichnoho upravlinnya pidpryyemstvom. [Directions and principles of development of modern strategic management of the enterprise.] Visnyk ZhDTU [Bulletin of ZhSTU]. No 2(56). Pp. 27-29. (in Ukrainian).

9. Koval'chuk S.V. (2010) Otsinyuvannya ekonomichnoyi stratehiyi promyslovykh pidpryyemstv u rynkovomu seredovyshchi [Estimation of economic strategy of industrial enterprises in the market environment]. Visnyk natsional'noho universytetu "L'vivs'ka politekhnika». [Kovalchuk // Bulletin of the National University "Lviv Polytechnic"]. No 690. Pp. 331-340. (in Ukrainian).

10. Malyarets' L.M., Achkasova O.V. (2012) Zbalansovana systema pokaznykiv yak instrument vyznachennya stratehiyi pidpryyemstva $v$ umovakh kryzy: Monohrafiya. [Balanced system of indicators as a tool for determining the strategy of the enterprise in a crisis: Monograph] - Kharkiv: 304p. (in Ukrainian).

11. Moyseyenko I.P. (2013) Stalyy ekonomichnyy rozvytok na osnovi stratehiyi ekonomichnoyi bezpeky. [Sustainable economic development based on economic security strategy]. Ekonomichnyy visnyk universytetu. [Economic Bulletin of the University]. Vol. 21(1). Pp. 172-176. (in Ukrainian).

12. Muzychenko A.S. (2014) Stan ta tendentsiyi rozvytku hirnycho-metalurhiynoho kompleksu Ukrayiny [State and trends of development of the mining and metallurgical complex of Ukraine.]. Ekonomichnyy forum. [Economic forum.]. No 3. Pp. 25-31. (in Ukrainian).

13. Pylypenko A.A. (2010) Zbalansovana systema pokaznykiv u systemi stratehichnoho upravlinnya rozvytkom intehrovanykh struktur biznesu [Balanced system of indicators in the system of strategic management of integrated business structures] // Problemy ekonomiky. [Problems of economy]. No2. Pp. 47-55. (in Ukrainian).

14. Pylypenko A.A. (2007) Orhanizatsiya upravlinnya intehrovanymy strukturamy biznesu $v$ konteksti zbalansovanoyi systemy pokaznykiv: Monohrafiya. [Organization of management of integrated business structures in the context of a balanced scorecard: Monograph]. Kharkiv. 152p. (in Ukrainian).

15. P"yatnyts'ka H.T. (2006) Upravlinnya pidpryyemstvom v epokhu hlobalizmu: Monohrafiya. [Enterprise Management in the Age of Globalism: Monograph.]. Kyiv. 568 p. (in Ukrainian).

16. Stel'mashchuk N.A. (2012) Upravlinnya ekonomichnoyu bezpekoyu rozvytku pidpryyemstva. [Upravlinnia ekonomichnoi bezpekoyu rozvytku pidpryiemstva] Stalyy rozvytok ekonomiky. [Sustainable economic development]. No 1. Pp. 68-74. (in Ukrainian).

17. Tkachuk I.H. (2008) Formuvannya finansovoyi stratehiyi v systemi upravlinnya pidpryyemstvom. [Formation of financial strategy in the enterprise management system]. Visnyk ZhDTU [Bulletin of ZhSTU]. No 2(44). Pp. 301-304. (in Ukrainian). 